\title{
Crisis and Organisational Innovation: Icelandic Local Government Responses
}

UDK: 338.124.4:352(491.1)(045)

\author{
Anna Cregård \\ School of Public Administration, University of Gothenburg, Sweden \\ anna.cregard@spa.gu.se \\ Rolf Solli \\ School of Business and IT, University of Borås, Sweden \\ rolf.solli@hb.se \\ Patrik Zapata \\ School of Public Administration, University of Gothenburg, Sweden \\ patrik.zapata@spa.gu.se
}

\begin{abstract}
This article examines the relationship between radical change in an institutional context and organisational innovation. It is based on an exploratory case study of three Icelandic local governments conducted in autumn 2010 and summer 2011. While many crises, when scrutinised closely, appear to be more like threats of crisis, Iceland's economic crisis is a genuine crisis with real and immediate effects. The three local governments studied responded to the crisis with actions that promote cooperation, reorganisation, acquiescence and involvement. The study demonstrates that most of these actions were reactive and somewhat non-innovative, though some were innovative - at least in this particular context.
\end{abstract}

Key words: innovation, local governments, Iceland, economic crisis, acquiescence

JEL: H83

\section{Introduction: Indigence is the mother of invention}

If one really must be innovative, one will be - or so the adage goes. When under pressure, we seem to be able to find ingenious, original and uncomplicated solutions deep within ourselves. If this is true of people, it should also be true of organisations, since they are made up of people. Organisations facing severe challenges have good opportunities to unleash their creative and troubleshooting energies, so a reasonable assumption would be that crises catalyse innovation (Behn, 1980). Literature on organisational innovation

Cregård, A., Solli, R., \& Zapata, P. (2012). Crisis and Organisational Innovation: Icelandic Local Government Responses. Uprava/Administration X(4), 35-49. 
indicates that this may be the case, at least for some organisations and under certain conditions (see discussion in Schroeder, Van de Ven, Scudder \& Polley, 1989; Slappendel, 1996), and literature on change management finds that this is fairly common (Rombach \& Solli, 2006).

Due to the crisis, government budgets have recently been severely cut in several European countries, notably Ireland, Iceland, Greece, Spain, Italy and Portugal. The long-term solvency of some of these countries is even in question. Other countries, both inside and outside the European Union, are scrutinising the effects of the economic crisis on the above countries, as the responses of their central governments are important for the world economy. However, economic crises of this magnitude affect not only central governments, but local ones as well. Local governments, located near the citizens, must handle individual tragedies such as unemployment, poverty and alienation, as well as the effects of institutional instability and distrust. If innovative action is needed anywhere, it is probably at this level. Interestingly, in an empirical study of three local governments in Sweden, Brorström (2012) found that the 2008/2009 crisis brought about actions identified as old solutions to old problems. However, Sweden's crisis was not nearly of the same magnitude as Iceland's. In fact, key actors in the local governments studied in Sweden did not even call the situation a crisis.

We seek examples of innovative local government actions in confronting the economic crisis. Our aim is to build knowledge of the relationship between radical change in the institutional context and organisational innovation; specifically, to build our knowledge of the organisational actions of local governments in response to the economic crisis.

Definitions of innovation from the literature refer to nearly anything concerning change. In this article, we define innovation (in administration) as a type of measure not previously encountered - at least not in response to the studied problem and organisational context (cf. Slappendel, 1996). Innovation - taken to refer to possible solutions to problems - has positive connotations as a prerequisite for making something different happen, for better or worse. An innovation is something that breaks from routine, tradition and formal and informal plans, causing an organisation to change course and head in a new direction.

Bureaucracy, the main structural principle of local governmental organisations, tends to dampen innovation (e.g., Mintzberg, 1979). However, local governments, like any organisations, are faced with a need to be innovative. This article is based on an exploratory case study conducted in November 2010, and a follow-up study from June 2011, of Icelandic local governments, which experienced a severe economic crisis in 2008. Iceland is an interesting case for research into institutional context and innovation. The entrepreneurial tradition is said to be strong in Iceland, and Icelanders' self-perception includes a sense of »making things work», often in novel 
ways. Individualistic perspectives on innovation regard this kind of culture and self-perception as important determinants of creativity and therefore of innovation (Knight, 1967; Sarros, Cooper \& Santora, 2008).

Iceland was chosen because of its context and history, and because its relatively small size facilitates study. The relationships between various sectors are close in Iceland, and the distances between people in different domains are not great. This closeness could enhance innovation, since it facilitates communication between the organisation and its context, for example, between local governments, state government and citizens (for a discussion of communication and innovation, see Saren, 1987). The local level is especially interesting, as it must handle demands from individuals and organisations while ensuring that local governmental organisation is robust.

\section{Responding to institutional processes:Analytical framework}

Crisis has no clear-cut definition. When a situation is labelled a crisis, someone is always defining it as such for a reason (Jönsson, 1982). Not least, new leaders tend to define the conditions prevailing during their takeover as constituting a crisis that necessitates changes (Rombach \& Solli, 2006). This rhetoric, if successful, can spur personnel to make organisational reforms.

The crisis examined here has inspired various accounts. It has been described quantitatively (SIC, 2010), for example in terms of the amount of money lost (in November 2008, Iceland's three big banks had to write down their assets by approximately 60\%), the percentage of people who lost work (this figure increased by approximately 360\% from August 2008 to February 2009), the number of people leaving Iceland (from net in-migration of 5,299 individuals in 2007 to out-migration of 2,369 in 2009). It has also been described qualitatively, in many tragic individual stories. The crisis is well known in Iceland and the rest of Europe, and the experts discussing the crisis in the media are renowned and credible. An economic crisis of this magnitude, which radically changes the conditions of local government activity, puts pressure on organisations to respond: the crisis must be handled in some way, supposedly by changes and actions appropriate to the new situation.

\subsection{Strategies and translation}

Neo-institutional theories highlight conformity and adaptation to social norms and rituals more than effective processes. Public policies, laws, values and beliefs in an organisational field are institutional constituents exerting isomorphic pressures on the organisational configuration. Bringing the environment into the organisation often results in inconsistencies between activities and external rituals, and decoupling is one way to resolve these (Brunsson, 1985; Meyer \& Rowan, 1977). Oliver (1991, p. 147) developed a typology of organisational strategies for responding to institutional 
pressures (conformity, acquiescence, compromise, avoidance, defiance and manipulation).

A later development in organisational studies was the »travel of ideas" metaphor, which moved theoretical development from a »diffusion« to a »translation « model in which institutional pressures, or rather external ideas, are translated, changed and localised in organisations (Callon, 1986; Czarniawska-Joerges \& Joerges, 1996). We use Oliver's typology and the translation model as analytical tools in this article.

\subsection{Traditional organisational responses to crisis}

Traditional cutback management literature is relatively homogeneous as regards the measures organisations should take when encountering crisis. While it is far from obvious that these measures necessarily succeed (Feldheim, 2007; Levine, 1979; Levine, Rubin \& Wolohojian, 1981; Nelson, 1998), they do indicate an ability to act and willingness to adapt. The literature presents various standard cutback measures, including:

- reducing staffing levels by attrition, hiring freezes, implementing RIF (reduction in workforce) plans, eliminating positions, early retirement, etc.;

- eliminating, reducing, and phasing out whole or parts of programmes;

- raising additional revenues from new sources;

- shifting responsibility for certain programmes to other agencies;

- deferring certain activities (e.g., building maintenance, renovations and studies);

- improving quality, efficiency and effectiveness (e.g., via process mapping and reengineering);

- using lower-cost labour (i.e., part-time workers, temporary workers and volunteers);

- using labour-saving approaches (i.e., increased use of technology and automation);

- providing incentives for resource conservation and performance improvement;

- reducing expenditures on selected budget items (e.g., travel and purchasing).

As mentioned above, crisis as a catalyst for innovation is the starting point of this article. If the Icelandic local governments had responded to the crisis using only the above measures, they could hardly be considered innovative, as these measures have all been used before. However, the way in which these measures were translated and communicated in the organisations could be innovative. The following sections present our methodology, followed by 
three empirical cases and a discussion. In the last section, we discuss our conclusions.

\section{Methodology}

We base our analysis on data from three local governments, the central government and the Association of Local Authorities in Iceland. We selected the local governments using snowball sampling. First, we chose Reykjavik because, as Iceland's largest local government, it could be expected to have taken many actions in response to the crisis. Then we chose Hafnarfjördur, which we learned was confronting major financial problems. Finally, we chose Borgarbyggd, which is well-known for major problems but, unlike the other two, has a relatively small population. The Association of Local Authorities and the central government body were selected because of their general knowledge of financial conditions and the information they could provide on specific local governments and their financial situations and actions.

Our research strategy has been pragmatic in that we have combined methods (Silverman, 1993) in order to understand and describe the institutional pressures on and responses of the studied local governments. It is also pragmatic in that it is neither purely inductive nor deductive, but follows a pattern of creative abduction (Schurz, 2008). Inspired by Strauss and Corbin (1990) and Charmaz (2006), our data processing involved iterative shifts between collecting, sorting, coding, categorising and probing the data and collecting new data, until we were able to reconstruct the relationship between the crisis and local government responses.

The data analysed were gathered on two field visits to Iceland in December 2010 and July 2011. We gathered data using a field-note diary and 17 personal interviews (Kvale, 1996) with key actors in the selected organisations, summarised in Table 1. All the selected interviewees gave their informed consent to participate in the study.

\section{Table 1: Interviewees}

\begin{tabular}{|l|l|l|}
\hline Organisations & Interviewees, visit 1 & Interviewees, visit 2 \\
\hline Reykjavik & $\begin{array}{l}\text { Director of Administration } \\
\text { Financial Manager }\end{array}$ & Director of Administration \\
\hline Hafnarfjördur & $\begin{array}{l}\text { Mayor } \\
\text { Financial Manager }\end{array}$ & Mayor (E-mail) \\
\hline Borgarbyggd & $\begin{array}{l}\text { Mayor } \\
\text { Project Leader in Infrastructure } \\
\text { Financial Manager }\end{array}$ & $\begin{array}{l}\text { Mayor } \\
\text { Financial Manager }\end{array}$ \\
\hline $\begin{array}{l}\text { Central government } \\
\text { (Department of Local } \\
\text { Authorities) }\end{array}$ & $\begin{array}{l}\text { Department Manager } \\
\text { Expert on Municipal Development }\end{array}$ & Department Manager \\
\hline $\begin{array}{l}\text { Association of Local } \\
\text { Authorities }\end{array}$ & $\begin{array}{l}\text { Managing Director } \\
\text { President } \\
\text { Director of Development and } \\
\text { International Affairs }\end{array}$ & Managing Director \\
\hline
\end{tabular}


On the first visit, a query template of 12 general questions, covering financial developments over the last decade, organisational responses to financial stress and effects inside and outside the organisations, guided all interviews. These questions were followed up by more specific questions. All interviews were recorded and transcribed verbatim. On the second visit, a smaller sample of key actors was interviewed (except in Hafnarfjördur, where we followed up by e-mail). The questions in the second round of interviews referred more specifically to local government actions taken to handle the financial and social situation. Each interview was led by one or two researchers and lasted two to three hours. During and between the visits, the research group met frequently to discuss findings and queries.

\section{Three Icelandic local governments and the crisis}

In winter 2008-2009, Iceland experienced one of the worst financial crises in its history as a result of the worldwide financial crisis, excessive public expenditures and excessive private spending. In 1994, the financial sector was deregulated and Icelandic banks were privatised. A new era in Icelandic banking had begun, and the new financial entrepreneurs were young, aggressive and risk-taking. Stories of the Icelandic financial market and business climate as a whole emphasised rapid decision-making, high profits, unconventional behaviour, close relationships and great creativity. At the local government level, substantial resources were spent on large projects that made Iceland seem a progressive and modern state with fantastic opportunities for citizens and tourists alike.

The oversized banking sector (approximately ten times the Icelandic GNP), the banking sector's risky investments and the small amount of Icelandic currency made the effects of the financial crisis especially large. In 2009, central government debt reached approximately EUR 150,000 per Icelander. This has had a major impact on the everyday life of every Icelander and has left the public sector struggling to satisfy citizen needs.

When the president of Iceland, Olafur Ragnar Grimson, declared Iceland bankrupt at the end of 2008, many strategies for handling the situation were devised. For example, the banks were put under state control, the banks' risky foreign investments were sold and a great deal of public expenditure was radically cut back. At the local government level, some structural changes were made, such as local government amalgamations.

\subsection{Reykjavik}

In most countries, a city the size of Reykjavik, Iceland's capital, would be considered small. Its population as of 1 January 2010 was 118,326, or $37 \%$ of the population of Iceland. Together with its surrounding local governments, the capital area has a population of 200,907 , or $63 \%$ of the population of Iceland. 
The financial crisis that struck in October 2008 obviously affected Reykjavik. However, since a local government is by definition local, a huge devaluation of the local currency does not particularly affect it, as most of its transactions are conducted in the local currency. The main problem for the city was the rapid increase in unemployment, from 1\% in 2007 to $9 \%$ in 2009, which meant higher costs and lower income for the city. The collapse of the building industry drastically reduced the expected revenue from the sale of building sites. Unfortunately, Reykjavik was investing intensely in an energy plant when the crisis struck. For this investment, the city had borrowed heavily in foreign currency; after devaluation, the cost of servicing this debt almost doubled in terms of the local currency.

The initial response was to unite all stakeholders. The city councillors set aside their differences to unite in crisis management activities, and an action group including members from both the majority and minority factions was established. This was done after years of conflict during which the city had seen, for example, four mayors in four years.

Budgeting for the time of crisis was based on three main principles: secured basic services for citizens, unchanged user fees and no layoffs of permanent city employees. Focusing on children and the elderly was a lesson learned from Finland. One of the first local government actions was to look closely at Finland, the Netherlands, Norway and other countries that had had to deal with major crises.

In the first round of cutbacks, the wages of most city officials and politicians were lowered. The mayor's salary was cut by $15 \%$, high officials' salaries by $10 \%$ and most other employees' salaries by $5 \%$. Those with the lowest earnings were not subject to pay cuts. New hiring was frozen, and a review board was created to oversee all new hiring in the administration. Total staffing of 8,000 was reduced by approximately 500 . International relations programmes were cut back.

City employees were motivated to offer ideas for cost savings through a special project: approximately 3,000 employees suggested 1,500 ideas, and approximately 300 of these were implemented immediately. These ideas included using energy-efficient instead of regular lighting, serving children porridge instead of cornflakes and letting the schools and kindergartens bake their own bread. According to our respondents, such cutbacks saved ISK 1.4 billion (EUR 9.6 million) as of January 2009.

In 2010, it became clear that the potential of conventional cutback measures had been exhausted, and that the initial response had not been enough. The focus now shifted to organisational reforms. Several reform projects were defined, each with a board that included stakeholders and change or project managers. For example, projects sought to: 
- reduce school system overhead by merging schools, playschools and daytime childcare where possible;

- restructure school canteens and establish joint kitchens for school meals;

- assist smaller local governments with human resources, finances, etc.

In summer 2011, Reykjavik was still in financial crisis, with unemployment at 8-9\%; the ISK was still weak, and other European countries were falling into crisis, making the financial climate difficult. Reykjavik, however, was planning optimistically. Although unemployment was high, the 2009 forecast had foreseen worse conditions.

\subsection{Hafnarfjördur}

Iceland's third largest town, Hafnarfjördur, has nearly 26,000 inhabitants and is situated in a bay just south of Reykjavik, between the capital and the international airport. Many of Hafnarfjördur's inhabitants work in or do business with Reykjavik, and its proximity to the capital boosted Hafnarfjördur's growth over the last decade. This potential for ongoing growth prompted the local government to invest heavily in projects to create new building land on the lava fields surrounding the town. These investments were paid for with foreign borrowing in euros, on the assumption that income from selling the land would cover the borrowing costs. However, the 2008 crisis made the land practically unsellable, and the local government even had to return deposits to some early buyers. All that is left of these projects is a network of streets, complete with streetlights, sewers and cables, but no houses.

Compared to many Icelandic local governments, Hafnarfjördur has an extensive public service, offering its inhabitants 15 kindergartens, eight primary schools, two secondary schools, various indoor sports facilities, harbour services, a library, music festivals, museums and - as the mayor put it - »everything a community needs to have. "Hafnarfjördur is proud of what it offers and people are still moving there.

The 2008 crisis led directly to decreased income and increased expenditures. The leaders of the three political parties represented on the city council discussed the situation, agreeing that the citizens and their welfare were most important. Together, they formulated three main lines of action. Firstly, cooperation between political parties would increase, given that the crisis was deemed more important than local politicking. Once or twice a week the three party leaders meet for three or four hours to discuss and analyse the progress made and to find new ways to continue making progress. Secondly, Hafnarfjördur is cooperating with other local governments to find solutions to their largely shared problems. Thirdly, Hafnarfjördur is trying to involve its inhabitants in the process, inviting them to open meetings at which the budget is discussed. All parties participate in this, even minority parties that 
before would simply blame any problems on the majority party. As the mayor says, »Things are different now - we have to think differently."

Organisationally, the crisis has prompted Hafnarfjördur to "cut the fat", as the mayor puts it: to cut management overtime, freeze hiring and generally reduce spending, eliminating all nonessentials. »This is not enough, " explains the mayor, "now we will have to cut to the bone." In practical terms, cutting »to the bone« translates into letting go of approximately 30 employees in the staff of 1,400 , merging education and welfare units and closing the planning unit. The last cut was not difficult, since Hafnarfjördur already has whole neighbourhoods planned and ready for construction.

\subsection{Borgarbyggd}

Borgarnes, the largest town in Borgarbyggd municipality, has approximately 2,000 inhabitants - over half the total population of the municipality. It is an important commercial town in western Iceland, and its economy is based primarily on commerce, farming and tourism. Since 1998, a tunnel under Hvalfjördur (»the whale fjord«) has facilitated travel to and from Reykjavik, making Borgarnes a popular place to live. Borgarbyggd represents the amalgamation of Borgarnes and several other local governments (Hraunhreppur, Alftaneshreppur and Borgarhreppur), making the local municipality relatively large in terms of both space and population.

From 1998 until the crisis in 2008, Borgarbyggd was developing well: the population was growing steadily by a few percent a year, the two universities (Bifröst University and the Agricultural University of Iceland) were attracting young people to the region and industry and tourism were growing. The local government's economy was sound and stable. The situation changed radically in 2008, when Borgarbyggd began struggling with outmigration, empty housing, rising unemployment and industry closures.

By late 2008, Borgarbyggd's economy was so poor that it had to report to a national government inspection authority. It also had to present an action plan, which was approved. This plan called for cutbacks in all service areas except social services, the need for which had increased. The local government found itself forced to sell all its shares in the local savings bank and thereby end an important relationship. Borgarbyggd also closed a day care centre and reduced the opening hours of those that remained. In the school sector, the town avoided a school closure (after major citizen protests), instead reorganising the school sector: now the elementary schools are organised into one school district instead of three, and education has been reorganised so that, for example, two classes can be taught together. Other cutbacks have resulted in reduced purchases of various products. The mayor says that services were increased in 2005 and 2006 - when smaller local governments were merged into a single larger one - to levels that now seem luxurious. It is not just the service level that has decreased. By cutting luxuries, 
Borgarbyggd has reduced its permanent staff by ten (of a total of 280). Overtime has also been cut and more people now work part-time. Salaries have decreased by $12-15 \%$ for top managers and by a lower percentage for those with lower earnings. Employees no longer receive compensation for travelling in their own cars when going to meetings; instead, the local government owns three cars that can be borrowed and has also tried to minimise the number of meetings.

Almost all measures to handle the crisis were implemented by the local government administration, though other community actors have also been involved. Local government and the local business community have met on the initiative of the local government to discuss the hard times, but have not tried to organise any joint action.

Although the municipal economy is currently strained, there аге some positive signs regarding the future. Not far from Borgarbyggd is a smelter that in recent years has employed almost 400 people, approximately $10 \%$ of whom live in Borgarbyggd. The mayor of Borgarbyggd says the smelter will attract other companies. Another positive development is the Landnamssetur (»The settlement centre« - a historical museum), which opened in 2006. It has received numerous awards and is attracting an increasing number of tourists.

\section{Discussion}

The actions taken in the three cases are summarised in Table 2. The local governments appear reactive rather than proactive and the key actors in our study seem to have fully mastered traditional cutback management (Feldheim, 2007; Levine, 1979; Nelson, 1998): they reduce, sell, close, freeze and reorganise. They also cooperate with various stakeholders and try to involve them in creating ideas and plans. Table 2 shows that local governments have acquiesced to and complied with expectations regarding how organisations usually handle financial crisis. They have accepted the norms.

Table 2: Actions taken

\begin{tabular}{|c|c|c|c|}
\hline Actions & Reykjavik & Hafnarfjördur & Borgarbyggd \\
\hline $\begin{array}{l}\text { Cooperation and } \\
\text { involvement }\end{array}$ & - Between political parties & $\begin{array}{l}\text { - Between political } \\
\text { parties } \\
\text { - With other local } \\
\text { governments } \\
\text { - With citizens }\end{array}$ & $\begin{array}{l}\text { - With business } \\
\text { community }\end{array}$ \\
\hline Reorganisation & $\begin{array}{l}\text { - Review board } \\
\text { - Change boards } \\
\text { - School sector mergers }\end{array}$ & $\begin{array}{l}\text { - Merging education } \\
\text { and welfare } \\
\text { - Planning unit closed }\end{array}$ & $\begin{array}{l}\text { - Reorganised school } \\
\text { sector }\end{array}$ \\
\hline Reduction & $\begin{array}{l}\text { - Salary cuts } \\
\text { - Cut in international } \\
\text { relations } \\
\text { - Employee cost-saving ideas } \\
\text { - No assistance to smaller } \\
\text { local governments }\end{array}$ & $\begin{array}{l}\text { - Reduced personnel } \\
\text { costs } \\
\text { - Reduced spending }\end{array}$ & $\begin{array}{l}\text { - Sold shares in bank } \\
\text { - Cutbacks in service } \\
\text { areas } \\
\text { - Closed day care centre } \\
\text { - Reduction in purchases } \\
\text { - Reduced personnel } \\
\text { costs }\end{array}$ \\
\hline
\end{tabular}


Were the local governments in the study innovative in their crisis handling? Their actions were mainly non-innovative, but some elements of their actions, when examined closely, should be considered innovative. Firstly, some actions are new in the local contexts studied. The local governments emulate what other local governments in other countries have done via measures not previously implemented in the new context. The change in institutional context - the crisis - imposes pressures for isomorphism (the reproduction of similar organisational structures), isopraxism (the standardisation of organisational practices) and isonymism (the imitation of organisational labels or names) (Erlingsdóttir \& Lindberg, 2005) that reflect organisations and organising practices in other countries, such as the Netherlands and the Scandinavian countries. While not innovative in a larger context, these changes are innovative in the local context. This search for useful ideas and experiences in other countries suggests that this is how the studied local governments manage to balance priorities and to bargain (Oliver, 1991, p. 147) with institutional stakeholders, such as creditors, central government inspection authorities and political opponents.

Secondly, the local governments may take actions that represent new responses to this kind of crisis. These actions seek to involve a broad range of actors and interests and entail a search for innovative solutions. One local government asked employees to come up with cost-saving measures, which led to a great number of useful ideas. Another local government sought to involve local residents, and yet another tried to involve and adapt to commercial and industrial conditions.

Crisis seems to be an opportunity to reorganise local government. The local governments in the study have reorganised vital parts of their services, and considered from a public opinion perspective this seems less onerous than shutting down schools and day care centres altogether. Politicians, employees and citizens protest less during a crisis, making change from a well-worn path to a new one more feasible.

Crisis represents an opportunity for some actors to facilitate change. It is an opportunity for new leaders - not politicians, but managers, administrators and controllers - to reshape their organisations into what they want them to be, and they often take advantage of this opportunity. These actors' arguments and language are developed in the management field (Rombach \& Zapata, 2010) and are well suited to turbulent situations. They take the opportunity to change what they want, possibly for reasons other than the crisis.

Our data indicate that two concepts merit discussion: cooperation and reorganisation. A crisis is a good opportunity to unify an organisation. In the local governments in the study, the crisis has led to less conflict, more collaboration and more joint action - antagonism is perceived as an inappropriate luxury in this situation. Various actors inside and outside 
the local government organisation seem to feel that they have a responsibility to act. In Oliver's (1991) terms, institutional pressure is being handled, not merely reactively and passively, but more actively. The key actors' tactics involve concepts such as balancing, pacifying and bargaining, but also coopting and influencing, important stakeholders. Local government strategies range from highly reactive and traditional to highly active and even innovative.

\section{Conclusions}

Our conclusions are derived from a specific context of harsh economic circumstances in a specific country. The local governments in the study are not average Icelandic local governments, as their financial conditions are more strained than in most cases. These governments were strategically chosen to facilitate a study of innovative actions taken in response to stressful economic situations. At the time of writing, many countries in Europe and elsewhere аге facing dire times, so the present results might be interesting from a broader perspective. We hope that studies of other local governments responding to crisis will follow.

During a crisis, a local government does not govern proactively, but mainly reactively. A local government does what its surroundings tell it to do - although possibly reluctantly. In the studied cases, creditors were the strongest external players: they wanted their money back and were largely unwilling to compromise. Others in the institutional field, such as the state, business community and voters, were also telling the local governments what to do. Local government somehow had to satisfy all demands simultaneously and, without sending conflicting messages, appear to function as normally as possible. During and after a crisis, measures are required in response to the crisis, external actors are constantly scrutinising the organisation's statements and actions, and the slightest deviations are noted and immediately reported. Under these circumstances, it is not easy to be innovative: if an organisation is supposed to do as it is told, then it can hardly do anything but acquiesce. As seen in this article, however, some of the actions taken were innovative - at least in this context and as solutions to particular problems - in embracing political cooperation and citizen involvement. To conclude, our main finding is that, although many actions were taken to deal with the crisis, most of them were reactive and somewhat non-innovative. 
Anna Cregård, Ph.D., is a research fellow and senior lecturer at the School of Public Administration, University of Gothenburg, Sweden. Her research deals with management and leadership in public organisations, sustainability accounting, complexity, and organisational change and development.

Rolf Solli, Ph.D., is a professor of Management at the Universities of Borås and Gothenburg, Sweden. His research deals with leadership, management, and accounting, mostly in the public sector.

Patrik Zapata, Ph.D., is an associate professor at the School of Public Administration, University of Gothenburg, Sweden. His research deals with the management of cities, sustainable organising, waste management, "scandalogy", and language in organisations. 


\section{References}

- Behn, R. D. (1980). Leadership for cut-back management: The use of corporate strategy. Public Administration Review 40(6), 613-620.

- Brorström, S. (2012). Local government actors' making sense of the financial crisis. Scandinavian Journal of Public Administration 16(1), 47-67.

- Brunsson, N. (1985). The irrational organization. Chichester, UK: John Wiley \& Sons.

- Callon, M. (1986). Some elements of a sociology of translation: Domestication of the scallops and the fishermen of St Brieuc Bay. In: Law, J. (Ed.), Power, action and belief: A new Sociology of Knowledge?(196-223). London: Routledge.

- Charmaz, K. (2006). Constructing grounded theory: A practical guide through qualitative analysis. Thousand Oaks, CA: Sage.

- Czarniawska-Joerges, B., \& Joerges, B. (1996). The travel of ideas. In: Czarniawska-Joerges, B., \& Sevón, G. (Eds.), Translating Organizational Change (13-48). Berlin: de Gruyter.

- Erlingsdóttir, G., \& Lindberg, K. (2005). Isomorphism, isopraxism and isonymism: Complementary or competing processes. In: Czarniawska, B. \& Sevón, G. (Eds.), Global ideas: How ideas, objects and practices travel in the global economy (47-70). Malmö, Sweden: Liber.

- Feldheim, M. A. (2007). Public sector downsizing and employee trust. International Journal of Public Administration 30(3), 249-270.

- Jönsson, S. (1982). A city facing stagnation. Stockholm: Statens råd för byggforskning-Studentlitteratur.

- Kvale, S. (1996). InterViews: An introduction to qualitative research interviewing. London: Sage.

- Knight, K. E. (1967). A descriptive model of the intra-firm innovation process. Journal of Business 40, 478-496.

- Levine, C. H. (1979). More on cutback management: Hard questions for hard times. Public Administration 39(2), 179-184.

- Levine, C. H., Rubin, S. R., \& Wolohojian, G. W. (1981). Resource scarcity and the reform model: The management of retrenchment in Cincinnati and Oakland. Public Administration Review 41(6), 619-628.

- Meyer, J. W., \& Rowan, B. (1977). Institutionalized organizations: Formal structure as myth and ceremony. American Journal of Sociology 83(2), 440463.

- Mintzberg, H. (1979). The structuring of organizations: A synthesis of research. Englewood Cliffs, NJ: Prentice-Hall.

- Nelson, B. (1998). The care of the un-downsized. Public Management 80(4), 20.

- Oliver, C. (1991). Strategic response to institutional processes. Academy of Management Review 16(1), 145-179.

- Rombach, B., \& Solli, R. (2006). Constructing leadership: Reflections on film heroes as leaders. Stockholm: Santérus Academic Press.

- Rombach, B., \& Zapata, P. (Eds.) (2010). The rise of management-speak. Stockholm: Santerus Academic Press.

- Saren, M. (1987). The role of strategy in technological innovation: A reassessment. In: Mangham, I. L. (Ed.), Organization analysis and development (125-165). Chichester, UK: Wiley. 
- Sarros, J. C., Cooper, B. K., \& Santora, J. C. (2008). Building a climate for innovation through transformational leadership and organizational culture. Journal of Leadership \& Organizational Studies 15(2), 145-158.

- Schroeder, R. G., Van de Ven, A. H., Scudder, G. D., \& Polley, D. (1989). The development of innovation ideas: Research on the management of innovation: The Minnesota studies. New York: Harper \& Row.

- Schurz, G. (2008). Patterns of abduction. Synthese 164(2), 201-234.

- Silverman, D. (1993). Interpreting qualitative data: Methods for analysing talk, text and interaction. London: Sage.

- SIC. (2010). Report of the Special Investigation Commission. Retrieved 5. 12 2012, from http://sic.althingi.is.

- Slappendel, C. (1996). Perspectives on innovation in organizations. Organization Studies 17(1), 107-129.

- Strauss, A., \& Corbin, J. (1990). Basics of qualitative research: Grounded theory procedures and techniques. London: Sage. 


\section{POVZETEK}

\section{KRIZA IN ORGANIZACIJSKA INOVATIVNOST: ODZIVI ISLANDSKE LOKALNE UPRAVE}

Ključne besede: inovacija, lokalna samouprava, Islandija, ekonomska kriza, pristajanje

\section{Revščina je mati izuma}

Če res moramo biti inovativni, tudi bomo - vsaj tako pravi pregovor. Ko smo pod pritiskom, smo globoko v sebi sposobni najti domiselne, izvirne in nezapletene rešitve. Če to velja za ljudi, bi moralo veljati tudi za organizacije, saj jih sestavljajo ljudje. Organizacije, ki se soočajo s težkimi izzivi, imajo dobro priložnost, da sprostijo svojo kreativno energijo in energijo za odpravljanje težav. Umestna je torej domneva, da bi krize morale sprožati inovacije. Literatura s področja organizacijske inovativnosti kaže, da je temu lahko tako, vsaj v nekaterih organizacijah in pod določenimi pogoji, in literatura o spremembah upravljanja ugotavlja, da je to precej pogosto.

Zaradi krize so v nekaterih evropskih državah močno oklestili proračune, zlasti na Irskem, Islandiji, v Grčiji, Španiji, Italiji in na Portugalskem, v državah, katerih dolgoročna plačilna sposobnost je sporna. Druge države, znotraj in izven Evropske unije, temeljito proučujejo vplive gospodarske krize v prej omenjenih državah, saj so odzivi njihovih vlad pomembni za svetovno gospodarstvo. Vendar pa gospodarske krize takšnega obsega ne vplivajo na državo samo na centralni ravni, temveč tudi na lokalni. Lokalne uprave, ki se nahajajo bliže državljanom, se morajo ukvarjati s problemi posameznikov, kot so nezaposlenost, revščina in odtujenost, kot tudi s posledicami institucionalne nestabilnosti in z nezaupanjem. Če so kje potrebna inovativna dejanja, potem je to verjetno na tej ravni. Zanimivo, Broström je v empirični študiji treh lokalnih uprav na Švedskem ugotovil, da je kriza v letih 2008/2009 pripeljala do ukrepov, prepoznanih kot stare rešitve za stare probleme. Vendar pa kriza na Švedskem ni bila niti približno tako razsežna kot na Islandiji. Pravzaprav je ključni akterji v proučevanih švedskih lokalnih upravah sploh niso imenovali kriza.

Iskali smo primere inovativnih dejanj lokalne uprave za soočanje z gospodarsko krizo. Naš cilj je bil ugotoviti odnos med korenito spremembo v institucionalnem okviru in organizacijsko inovativnostjo; konkretno, proučiti organizacijska dejanja lokalnih uprav kot odziv na gospodarsko krizo.

Islandija je bila izbrana za proučevanje zaradi njenega konteksta in zgodovine ter ker njena relativno majhna velikost lajša proučevanje. Na Islandiji so posamezni sektorji med seboj tesno povezani, razdalje med ljudmi na različnih področjih niso velike. Bližina bi lahko povečala inovativnost, saj lajša komuniciranje med organizacijo in njenim kontekstom, na primer, med lokalno 
upravo, državo in državljani. Lokalna raven je še posebej zanimiva, saj se mora ukvarjati z zahtevami posameznikov in organizacij in hkrati zagotavljati stabilnost lokalne uprave.

\section{Odzivi na institucionalne postopke: analitični okvir}

Kriza nima jasne definicije. Ko je situacija označena kot kriza, jo vedno nekdo kot tako definira z razlogom. Ne nazadnje, novi voditelji radi trdijo, da pogoji, ki prevladujejo med njihovim prevzemom, povzročajo krizo, kar zahteva spremembe. Takšna retorika, če je uspešna, lahko spodbudi ljudi k organizacijskim reformam.

Krizo, ki jo obravnavamo tukaj, so opisovali različno. Opisovali so jo kvantitativno z vidika, na primer, vsote izgubljenega denarja (novembra 2008 so tri velike islandske banke morale odpisati približno 60 \% premoženja), odstotka ljudi, ki so izgubili zaposlitev (povečal se je za približno 360 \% od avgusta 2008 do februarja 2009), števila ljudi, ki so zapustili Islandijo (od neto 5299 posameznikov, ki so se priselili leta 2007, do 2369 posameznikov, ki so se odselili leta 2009). Opisovali so jo tudi kvalitativno, z mnogimi tragičnimi individualnimi zgodbami. Na Islandiji in v preostali Evropi je kriza dobro poznana in strokovnjaki, ki razpravljajo o krizi v medijih, so priznani in zaupanja vredni. Gospodarska kriza takšne razsežnosti, ki korenito spremeni pogoje aktivnosti lokalnih uprav, pritiska na organizacije, da se odzovejo; s krizo se je treba na neki način spoprijeti, torej s spremembami in dejanji, primernimi novim razmeram.

Neoinstitucionalne teorije poudarjajo pomen usklajenosti in prilagojenosti socialnim normam in običajem, bolj kot pomen uspešnosti procesov. Na organizacijsko obliko enako vplivajo javna politika, zakoni, vrednote in prepričanja v organizaciji. Oliver je razvil tipologijo organizacijskih strategij, ki se uporablja kot analitično orodje v tem članku, tj. usklajevanje, pristajanje, kompromis, izogibanje, kljubovanje in manipulacija kot odziv na institucionalne pritiske.

\section{Metodologija}

Naša analiza temelji na podatkih treh lokalnih uprav, centralne vlade in Združenja lokalnih oblasti na Islandiji. Naša raziskovalna strategija je bila pragmatična v tem, da smo združili metode z namenom, da bi razumeli in opisali institucionalne pritiske na lokalne uprave in njihove odzive. Pragmatična je tudi v tem, da ni ne izključno induktivna ne deduktivna, ampak sledi vzorcu kreativne abdukcije. Upoštevajoč ugotovitve Straussa in Corbina ter Charmaza je naše obdelovanje podatkov vključevalo večkratno ponavljanje zbiranja, urejanja, šifriranja, kategoriziranja in preverjanja podatkov ter zbiranja novih podatkov, dokler nam ni uspelo rekonstruirati odnosa med krizo in odzivom lokalnih uprav. 
Proučevane lokalne uprave niso povprečne islandske lokalne uprave, saj je njihov finančni položaj bolj kritičen kot pri večini. Bile so strateško izbrane, da bi olajšale proučevanje inovativnih dejanj kot odziva na krizne gospodarske razmere. Analizirani podatki so bili zbrani med dvema obiskoma Islandije, decembra 2010 in julija 2011.

\section{Zaključki}

$\checkmark$ tem času se številne države v Evropi in svetu soočajo s težkimi časi, zato bi bili pričujoči rezultati lahko zanimivi iz širše perspektive. Upamo, da bodo sledile nove študije o odzivih lokalnih uprav na krizo.

V času krize lokalne uprave ne upravljajo proaktivno, ampak večinoma reaktivno. Lokalna uprava naredi, kar zahteva okolje - čeprav verjetno nerada. V preučevanih primerih so bili upniki najmočnejši zunanji akterji: nazaj so hoteli svoj denar in se niso bili pripravljeni veliko pogajati. Vendar so drugi akterji na institucionalnem področju, kot npr. država, poslovna skupnost in volivci, prav tako narekovali lokalni upravi, kako ukrepati. Lokalna uprava je morala nekako zadovoljiti vse zahteve in je morala hkrati delovati čim bolj normalno. Med krizo in po njej so potrebni ukrepi kot odziv na krizo, zunanji akterji neprestano pregledujejo izjave in dejanja organizacije in vsako najmanjše odstopanje se opazi ter nemudoma objavi. V takih pogojih ni lahko biti inovativen: če naj bi organizacija poslovala tako, kot od nje pričakujejo drugi, ji ne preostane veliko možnosti za inovacije. Kot pa je razvidno iz članka, je nekaj ukrepov bilo inovativnih - vsaj v kontekstu krize in kot rešitev za določene probleme glede pristajanja na politično sodelovanje in vključenost državljanov. Taktika prepričevanja ključnih akterjev zahteva usklajevanje, pomirjanje in pogajanje, pa tudi izbiranje pomembnih deležnikov in vplivanje nanje.

Kriza je dobra priložnost za poenotenje zaposlenih v organizaciji. V proučevanih lokalnih upravah je kriza povzročila manj konfliktov, omogočala več sodelovanja - antagonizem se v krizni situaciji dojema kot neprimerno razkošje. Zdi se, da se različni akterji, znotraj in izven organizacije lokalne uprave, zavedajo odgovornosti za ukrepanje. Naša glavna ugotovitev pa je, da je bila večina ukrepov reaktivnih in nekoliko neinovativnih, čeprav so bili sprejeti za spopadanje s krizo. 